\title{
Oestrogen and progesterone receptors in bilateral and unilateral pubertal gynecomastia - is treatment with anti-oestrogens justified?
}

\section{Receptory estrogenowe i progesteronowe w obustronnej oraz jednostronnej ginekomastii pokwitaniowej - czy leczenie lekami antyestrogenowymi jest uzasadnione?}

\author{
Kaja Giżewska-Kacprzak ${ }^{1 凶}$, Jacek Materny ${ }^{1}$, Elżbieta Gawrych ${ }^{1}$, Katarzyna Karpińska-Kaczmarczyk², \\ Magdalena Lewandowska²
}

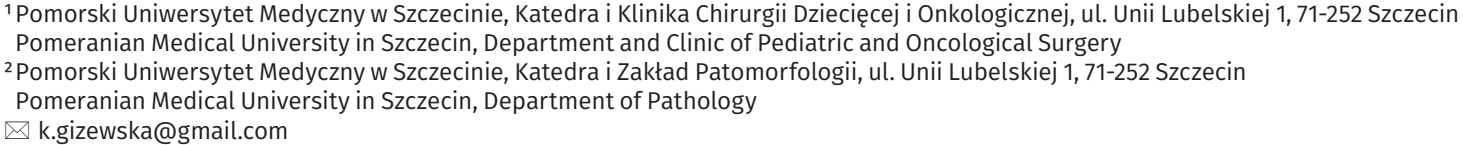

\begin{abstract}
Introduction: Pubertal gynecomastia (PG) is a benign enlargement of the breast that affects more than half of boys in puberty. In unclear aetiology there is no explanation for unilateral cases. The most common treatment in persistent cases is surgical removal, but this is associated with certain risks.

The aim of the study is to compare oestrogen receptors (ER) and progesterone receptors (PR) status in unilateral and bilateral PG, and to present possible clinical application of the results.

Materials and methods: A retrospective review of 30 patients operated on for PG was performed with immunohistochemical analysis of ER and PR in the resected tissue. Unilateral (8) and bilateral (22) cases were compared.
\end{abstract}

Results: Oestrogen and progesterone receptors were present in all of the examined specimens. There was a significantly higher percentage of ER and PR positive nuclei in tissue from bilateral $P G$ than in material from unilateral cases. A positive correlation between the presence of ER and PR was found. Age at the time of surgery was not a significant factor.

Conclusions: Oestrogen and progesterone receptors may play a role in the aetiology of PG, especially in bilateral cases. Our results are a good starting point for studies on differences between unilateral and bilateral PG. There is a need for randomized placebo controlled trials on the use of anti-oestrogen drugs to explore pharmacological alternatives to surgical treatment of PG. Keywords: pubertal gynecomastia; unilateral; bilateral; oestrogen receptor; progesterone receptor.

\begin{abstract}
ABSTRAKT
Wstęp: Ginekomastia pokwitaniowa (GP) jest łagodnym powiększeniem gruczołów piersiowych u mężczyzn, które występuje u ponad połowy chłopców w wieku pokwitaniowym. W niejasnej etiologii ginekomastii nie ma również wyjaśnienia przyczyny przypadków jednostronnej GP. Najczęstszą metodą leczenia przetrwałych przypadków jest zabieg operacyjny, obciążony ryzykiem powikłań.

Celem badania było porównanie występowania receptorów estrogenowych (ER) i progesteronowych (PR) w jednostronnej i obustronnej GP z oceną możliwego klinicznego zastosowania wyników.

Materiały i metody: Przeprowadzono retrospektywną analizę dokumentacji 30 pacjentów operowanych z powodu GP z wtórną oceną immunohistochemiczną występowania ER i PR w wyciętych preparatach. Porównano przypadki jednostronne (8) z obustronnymi (22).
\end{abstract}

Wyniki: Receptory estrogenowe i progesteronowe były obecne we wszystkich przebadanych preparatach. Stwierdzono statystycznie istotnie wyższy odsetek jąder komórkowych z ER i PR w materiale obustronnych GP niż w przypadkach jednostronnej patologii. Została stwierdzona dodatnia korelacja pomiędzy występowaniem obu typów receptorów. Wiek pacjentów w chwili operacji nie był istotnym czynnikiem.

Wnioski: Receptory estrogenowe i progesteronowe mogą odgrywać istotną rolę w etiologii ginekomastii, szczególnie w przypadkach obustronnych. Uzyskane wyniki stanowią punkt wyjścia do dalszych badań nad różnicami pomiędzy jednostronną a obustronną ginekomastią. Randomizowane badania prospektywne oceniające skuteczność terapii GP lekami antyestrogenowymi mogłyby przyczynić się do ustalenia farmakologicznej alternatywny dla leczenia chirurgicznego.

Słowa kluczowe: ginekomastia pokwitaniowa; jednostronna; obustronna; receptor estrogenowy; receptor progesteronowy.

\section{INTRODUCTION}

Gynecomastia is a benign enlargement of the male breast. It can be physiological, drug-related, iatrogenic or a sign of a range of pathological conditions [1]. Pubertal gynecomastia (PG) affects over half of teenagers. It reaches its peak of incidence at the age of 14 years and in its natural course is usually transient [2]. Persistent cases require differential diagnostic measures to exclude underlying disorders. If systemic disorders or reversible causes are excluded, the condition can be managed 
as benign. Pubertal gynecomastia can cause inconvenient tenderness and pain in breasts. What is crucial is that clearly enlarged breasts cause great emotional distress in boys [3]. The most common treatment option is surgery, which, like any other invasive procedure, has its risks and downsides [4, 5].

While the underlying pathomechanism of the condition is still unclear, the quest for a deeper understanding of the aetiology has been launched to find treatment alternatives, such as pharmacotherapy targeted at a possible cause. It has been suggested that a short-time imbalance of oestrogen and androgen could be responsible for gynecomastia $[6,7,8]$. There are reports which show no differences in sex hormone profiles between patients with PG and controls, as well as suggestions that classic diagnostic measures could not catch evident abnormalities in hormone profiles at the stage of the developed condition $[9,10]$. The research was focused on histopathological analysis to prove the hypothesis of the hypersensitivity of breast tissue to hormones. There are contradictory reports that blur the oestrogen receptor (ER) and progesterone receptor (PR) status of PG [11,12].

This study was designed to clarify if ER and PR are present in this condition, and what clinical benefits can be gained from establishing their presence. Methods widely used in the qualification of female breast cancer patients were adapted to this study. Moreover, so far there has been no publication comparing bilateral and unilateral PG regarding ER and PR status. Therefore, our goal was to search for differences in the presence of the above-mentioned receptors in those 2 types of PG.

\section{MATERIALS AND METHODS}

A retrospective analysis was conducted of patients operated on from 2000 to 2014 for bilateral and unilateral PG at our department. Apart from a medical history file review, all of the archived histopathological specimens were carefully revaluated. Resected tissue was preserved in a solution of $10 \%$ neutral buffered formalin, and was embedded in paraffin to prepare blocks for archiving. Sectioned and stained specimens were examined after surgery to exclude malignancy. At time of this

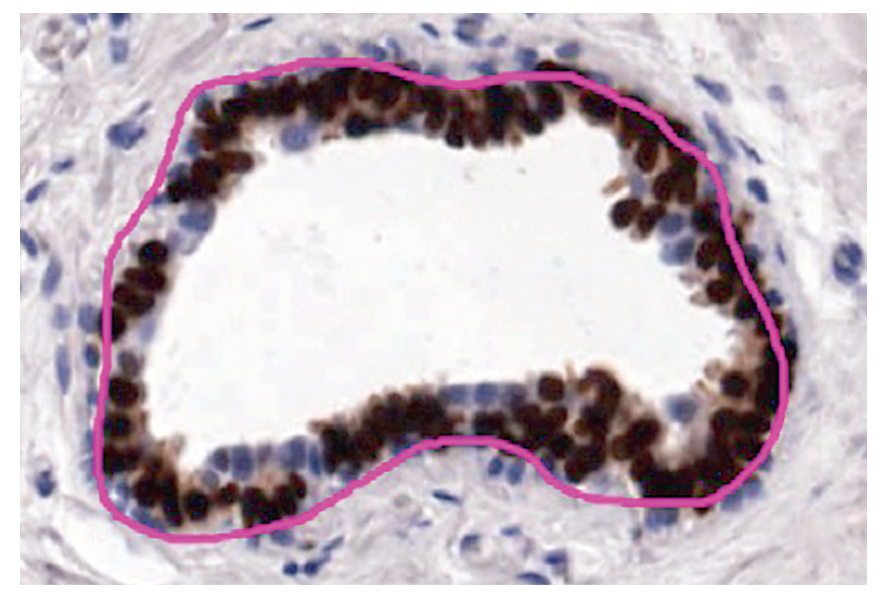

FIGURE 1. Outlined region of interest in a specimen prepared for oestrogen receptor analysis study they were deparaffinised for 60 minutes at 58 degrees Celsius to prepare specimens for further immunohistochemical diagnostic tests. Antigens were revealed with Autostainer Link 48, EnVision TM FLEX Target Retrieval Solution and Linker. Later, primary monoclonal antibodies specific for ER (IR08461-2 FLEX Monoclonal Rabbit X-H ER alpha Clone EP1. RTU, Link) and PR (IRo6861-2 FLEX Monoclonal Mouse, X-Hu Progest Recept Clone PgR 636 RTU, Link) were applied. All reagents were from Dako Denmark A/S.

Specimens were scanned, digitalized and magnified. An image computer analysis using the nuclear Vy algorithm from Aperio ScanScope XT SYTEMS, Aperio Technologies was used to quantify the percentage of positive nuclei with ER and PR in the selected region of interest (ROI). Regions were selected and carefully outlined by the author at the line of ductal epithelial cells in the glandular area (Fig. 1 and 2). This part of the study was blinded, as the researcher was not aware of which patient's specimen was being analyzed. Later results were categorized and divided into 2 groups - unilateral and bilateral PG. Statistical analysis was performed considering $\mathrm{p}<0.05$ to indicate a significant difference.

\section{RESULTS}

The data of 30 adolescent boys operated on for PG were assessed, as material from 2 other patients was not of adequate quality for full analysis. Patients were divided into 2 groups ( 22 bilateral gynecomastia cases and 8 unilateral cases). The mean age of patients at the time of surgery was 16.6 years (14.2-18.6) with no difference between both groups. Prior to surgery all of the patients underwent paediatric and endocrinal examination, including relevant family history and appropriate clinical tests. Hormone profile included testosterone, estradiol, luteinizing hormone, follicle-stimulating hormone, human chorionic gonadotropin and thyroid hormones. All results were within normal ranges for sex and age. When boys reached surgical qualification, endocrine, external or iatrogenic causes of gynecomastia had already been excluded. In all of cases the time

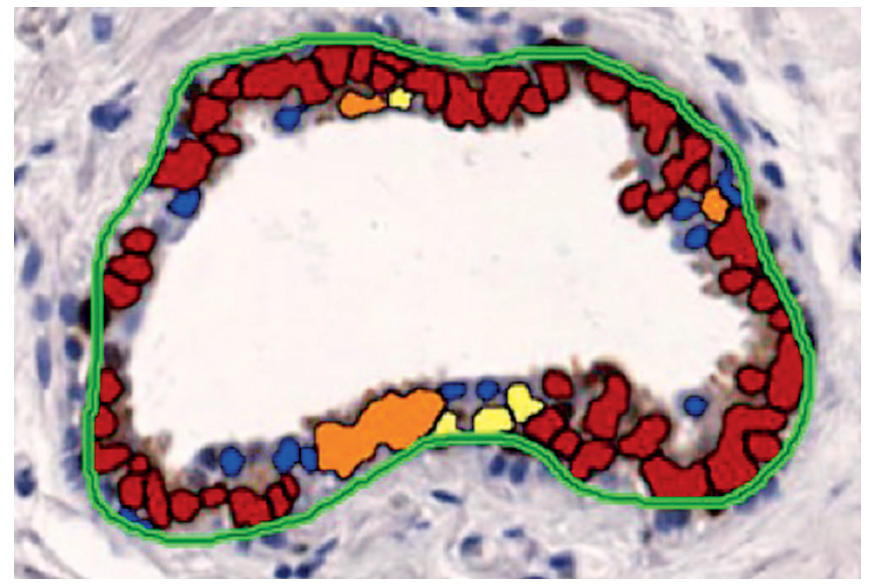

FIGURE 2. The same region of interest after the computer analysis with colour variation corresponding with oestrogen receptor positive nuclei 
from the beginning of diagnosis to surgery was at least 1 year. Ultrasound examination was performed in all cases to confirm the diagnosis. In cases with an evident fatty tissue component patients received dietary consultations, and surgeries were performed after a certain time of weight reduction.

Patients underwent partial mastectomy from perialeolar incision with good cosmetic outcome and no post-surgical complications. Resected tissue specimens were sent to pathology and none of them showed malignancy in histopathological examination.

Immunohistochemical methods together with computer processing enabled the assessment of the expression of ER and PR in nuclei of the examined tissue. In all of the specimens both types of receptors were present. In unilateral cases ER were present on average in $68.16 \%$ of the examined nuclei, while PR were present in $73.08 \%$ of them. In bilateral specimens an average of $80.90 \%$ of the examined nuclei were positive for ER and $80.19 \%$ for PR. There were more ER and PR in bilateral cases in comparison to unilateral patients, and the difference was statistically significant (ER: $p=0.0012$; PR: $p=0.0391$; Fig. 3 and 4). There was a positive correlation between both types of receptors $(r=0.32 ; p=0.0340)$. We found no correlation between the age of patients and expression of the examined receptors (ER: $r=0.03 ; p=0.8602 ; P R: r=-0.02 ; p=0.8824$ ).

There was no statistically significant difference in the results of pairs of specimens from bilateral gynecomastia, which proved the objectivity of the applied blinded measuring method. Moreover, there was no correlation between the number of counted nuclei in ROI and the results of both types of receptor

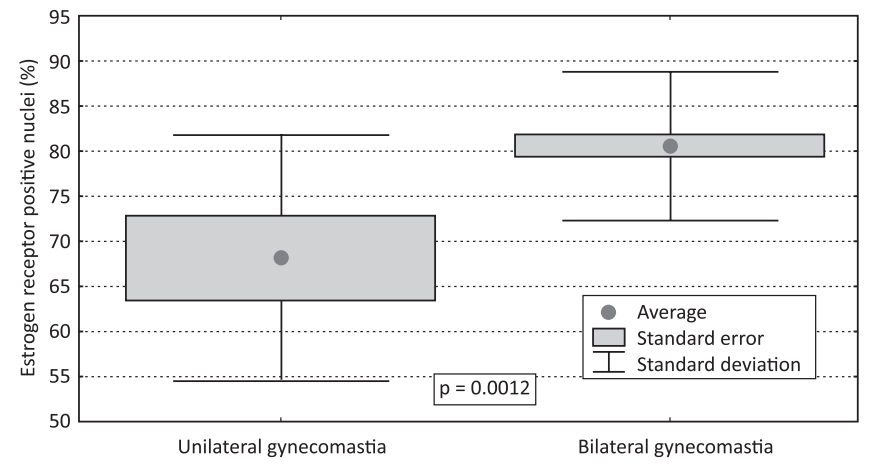

FIGURE 3. Oestrogen receptor expression in unilateral and bilateral gynecomastia

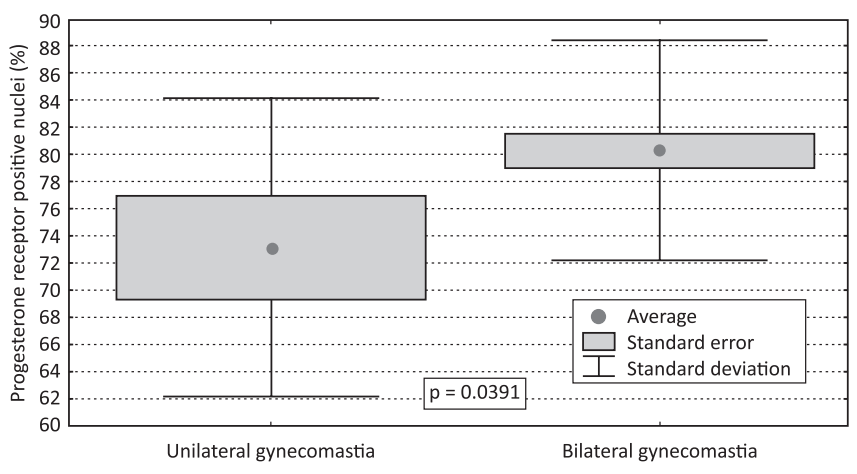

FIGURE 4. Progesterone receptor expression in unilateral and bilateral gynecomastia analysis (ER: $r=-0.13 ; p=0.3892 ;$ PR: $r=-0.02 ; p=0.9010$ ), which also proves that our methodology did not bias the results.

\section{DISCUSSION}

Gynecomastia is found in up to $70 \%$ of boys at time of puberty. Only $10 \%$ of patients have unilateral condition, and it is unclear why some patients manifest single-sided enlargement of the breast [13]. There are a few case reports of unilateral gynecomastia, including prepubertal cases or individual adult patients, such as 1 tennis player and a patient on isoniazid therapy $[14,15]$. In our study group there was a surprisingly large group of 8 patients with unilateral gynecomastia, with an average age 16.5 at the time of surgery. Demirbilek et al. reported 2 cases of unilateral prepubertal gynecomastia, aged 8 and 9, with full endocrinological and oncological work-up. Authors found $100 \%$ of epithelial periductal cells positive with intense cytosolic and nuclear staining of ER. They suggest that possible local oestrogen hypersensitivity could be responsible for unilateral localization of the lesion [16]. Study limitations included the ethical point of the impossibility to compare tissue from an enlarged breast to the healthy one on the other side in unilateral cases to prove such a hypothesis. Our results on slightly older patients also presented ER receptors in unilateral cases. In our material we found a significantly higher percentage of positive nuclei, both ER and PR, in bilateral cases than in unilateral ones, which calls attention to dissimilarities between those conditions. Future studies could thoroughly examine the differences between prepubertal and pubertal gynecomastia, as well as unilateral and bilateral cases.

Idiopathic PG is often temporary, and spontaneous remission may occur in up to $75 \%$ of cases. In persistent conditions the most widely used intervention is mastectomy. Such an invasive treatment exposes the patient to risk of wound infection, postoperative numbness and hypertrophic scar formation. Moreover, some authors observed a recurrent hypertrophic gland, declaring surgery ineffective. The most up-to-date surgical intervention is a combination of an open technique with minimally invasive liposuction [17]. Our patients underwent mastectomy from the perialeolar incision. A thin pad of tissue was left to achieve a natural outcome. In both of our groups we had a positive cosmetic outcome with no postoperative complications in wound healing.

Male breast cancer is a rare condition (0.5-1\%). Unfortunately, it is usually diagnosed late, at more advanced stage compared to female cases [18]. Histopathological examinations of all specimens did not reveal any worrying findings. In a pathological retrospective and a literature review of both paediatric and adult patients Senger et al. suggested that routine histopathological examination of tissue after surgical removal of gynecomastia should be reassessed due to the high cost and only incidental cancerous findings in the literature [19]. Nevertheless, in our protocol all of the collected tissue specimens are being sent to pathologists as a sign of the responsibility of being aware of what was resected from the child's body. 
The aetiology of gynecomastia is complex, as many conditions can include its appearance. Idiopathic PG has been a topic of various studies, with some directed at establishing the role of tissue receptors. Pensler et al. presented elevated ER and PR in patients with Klinefelter syndrome compared to adolescent boys with idiopathic gynecomastia. The authors conclude their work linking their results with a higher risk of malignancy in the Klinefelter syndrome. Researchers used measures that enable the comparison of concentrations of ER and PR in cytosol protein. The controversial cut-off point was selected at $1 \mathrm{fmol} / \mathrm{mg}$ cytosol to distinguish negative cases. In the study, all of the patients with idiopathic gynecomastia with 46 XY karyotype were negative for both ER and PR [11]. In contrast, in our study we applied methods widely used in the histopathological examination of female breast cancer in the qualification for anti-oestrogen therapy. Specimens underwent immunohistochemical pretreatment with monoclonal antibodies to present ER and PR positive nuclei in ductal cells. As our study group consisted of both bilateral and unilateral cases, we wanted to avoid bias due to the preselection of specimen, so our computer analysis was blinded and results were divided into 2 groups when the analysis was completed. In oncologic qualification for anti-oestrogen therapy female breast cancer patients are qualified for treatment if immunohistochemical analysis of the resected tumour tissue is either $\mathrm{ER}+/ \mathrm{PR}+$ or ER-/PR+. The only situation when therapy is not introduced is when neither ER nor PR have been found. Patients are offered anti-oestrogen treatment to support the effects of surgical removal of the tumour [20]. In our study ER and PR were present in all of the examined specimens. What is more, there was a strong correlation between both receptors. Assuming that all idiopathic PG are ER and PR positive, pharmacotherapy could be introduced prior to invasive procedures. This is a strong basis for promoting pharmacological studies to offer patients alternative treatment options, shifting surgical removal to last choice.

Our results are a good starting point for further studies. An extensive search for further differences between unilateral and bilateral PG could possibly improve and individualize the future treatment of those patients. The next possible research direction should be focused on anti-oestrogen therapy for PG. There are numerous reports on tamoxifen in treating adults, and some about pubertal patients [21]. Therefore, the alternative pharmacological anti-oestrogen drug raloxifen offers better outcomes compared to tamoxifen, and tends to be less aggravating for young patients [22]. The authors present positive outcomes, but limits include imperfect outcome measures and no comparison to any control of the placebo group. Hanavadi et al., in research regarding adults treated with tamoxifen (mean age of the study group 36 years), reported discontinuation of the pharmacotherapy only in 1 patient with calf tenderness [21]. No side effects of tamoxifen therapy were reported in the treatment of PG, including a years-long follow up study [23]. In a systemic review by Lapid et al. no randomized placebo controlled studies were found [24]. Studies published so far have not revealed dangerous side effects, and present promising results. Future studies could build a new clear treatment protocol including both pharmacological alternatives and sophisticated minimally invasive surgical options. Emphasis should be put on an individual approach, including time of treatment introduction, to reduce patients' discomfort and stress.

Nevertheless, there has been no thorough treatment protocol yet published [25]. It is suggested that pharmacotherapy should be implemented early enough to have beneficial effects, before gynecomastia becomes fibrotic [26]. On the other hand, it is unclear where the line between persistent gynecomastia and natural course of the condition lies. In our study group all of the patients had at least a year-long history of significant breast enlargement. We suggest that this time could be used for a non-surgical approach, which can have a positive impact on patients' perception of treatment measures.

Supporting the holistic approach, physicians should not forget about the emotional burden of PG. Anxiety, embarrassment, low self-esteem, followed by depression put a huge amount of stress on men with gynecomastia at any age [27]. Emotional distress in puberty can appear naturally, and therefore boys with PG are in a very difficult position regarding their body image [28]. Both paediatricians and paediatric surgeons should have in mind possible psychiatric consultation to support both patients and parents at this difficult time. Our results, which contribute to the development of accurate pharmacological protocols of treatment, could also be a trigger to widen the common surgical approach to $\mathrm{PG}$, and put the time factor under the spotlight. Pharmacotherapy could be sufficient in mild cases, or be applied prior to surgery to reduce the extent of surgery.

\section{CONCLUSIONS}

In conclusion, ER and PR are present in both unilateral and bilateral PG. Our results, which show higher percentage of both receptors in bilateral cases, are a good starting point for the further exploration of differences between unilateral and bilateral PG. Randomized placebo controlled trials on the use of anti-oestrogen drugs are needed to establish pharmacological alternatives to surgical treatment of PG.

\section{REFERENCES}

1. Dickson G. Gynecomastia. Am Fam Physician 2012;85(7):716-72.

2. Lawrence SE, Faught KA, Vethamuthu J, Lawson ML. Beneficial effects of raloxifene and tamoxifen in the treatment of pubertal gynecomastia. J Pediatr 2014;145(1):71-6. doi: 10.1016/j.jpeds.2004.03.057.

3. Nuzzi LC, Cerrato FE, Erikson CR, Webb ML, Rosen H, Walsh EM, et al. Psychosocial impact of adolescent gynecomastia: a prospective casecontrol study. Plast Recontr Surg 2013;131(4):890-6. doi: 10.1097/ PRS.0b013e3182818ea8.

4. Ersek RA, Schaeferele M, Beckham PH, Sallsbury MA. Gynecomastia: a clinical review. Aesthet Surg J 2000;20(5):381-6.

5. Ratnam BV.A new classification and treatment protocol for gynecomastia. Aesthet Surg J 2009;29(1):26-31. doi: 10.1016/j.asj.2008.11.003.

6. Griffin JE, Wilson JD: Abnormalities in estrogen metabolism. In: Williams texbook of endocrinology, 10th Ed. Philadelphia: Sauders; 2003. p. 741-6. 
7. Bulard J, Mowszowicz I, Schaison G. Increased aromatase activity in pubic skin fibroblasts from patients with isolated gynecomastia. J Clin Endocrinol Metab 1987;64(3):618-23. doi: 10.1210/jcem-64-3-618.

8. Moore DC, Schlaepfer LV, Paunier L, Sizonenko PC. Hormonal changes during puberty: V. Transient pubertal gynecomastia: abnormal androgen estrogen ratios. J Clin Endocrinol Metab 1984;58(3):492-9. doi: 10.1210/ jcem-58-3-492.

9. Large DM, Anderson DC. Twenty-four hour profiles of circulating androgens and oestrogens in male puberty with and without gynaecomastia. Clin Endocrinol (Oxf) 1979;11(5):505-2.

10. Nuttall FQ, Warrier RS, Gannon MC. Gynecomastia and drugs: a critical evaluation of the literature. Eur J Clin Pharmacol 2015;71(5):569-78. doi: 10.1007/s00228-015-1835-x.

11. Pensler JM, Silverman BL, Sanghavi J, Goolsby C, Speck G, Brizio-Molteni L, et al. Estrogen and progesterone receptors in gynecomastia. Plast Reconstr Surg 2000;106(5):1011-3.

12. Sasano H, Kimura M, Shizawa S, Kimura N, Nagura H. Aromatase and steroid receptors in gynecomastia and male breast carcinoma: an immunohistochemical study. J Clin Endocrinol Metab 1996;81(8):3063-7. doi: 10.1210/jcem.81.8.8768875.

13. Hoevenaren IA, Schott DA, Otten BJ, Kroese-Deutman HC. Prepubertal unilateral gynecomastia: a report of two cases. Eur J Plast Surg 2011;34(5):395-8. doi: 10.1007/s00238-010-0469-6.

14. Kang SG, Song WJ, Kim CH, Kim JW, Tark MS. Unilateral gynecomastia in a tennis player. Arch Plast Surg 2012;39(6):675-8. doi: 10.5999/ aps.2012.39.6.675.

15. Goud BK, Devi OS, Nayal B, Devaki RN. A rare case of unilateral gynecomastia during antituberculous chemotherapy with isoniazid. Indian J Pharmacol 2012;44(4):521-2. doi: 10.4103/0253-7613.99340.

16. Demirbilek H, Bacak G, Baran RT, Avci Y, Baran A, Keles A, et al. Prepubertal unilateral gynecomastia: report of 2 cases. J Clin Res Pediatr Endocrinol 2014;6(4):250-3. doi: 10.4274/Jcrpe.1477.

17. Fischer S, Hirsch T, Hirche C, Kiefer J, Kueckelhaus M, Germann G, et al. Surgical treatment of primary gynecomastia in children and adolescents. Pediatr Surg Int 2014;30(6):641-7. doi: 10.1007/s00383-014-3508-8.
18. Vermeulen JF, Kornegoor R, van der Wall E, van der Groep P, van Diest PJ. Differential expression of growth factor receptors and membrane-bound tumor markers for imaging in male and female breast cancer. PLoS One 2013;8(1):e53353. doi: 10.1371/journal.pone.0053353.

19. Senger JL, Chandran G, Kanthan R. Is routine pathological evaluation of tissue from gynecomastia necessary? A 15-year retrospective pathological and literature review. Plast Surg (Oakv) 2014;22(2):112-6.

20. Hammond ME, Hayes DF, Dowsett M, Allred DC, Hagerty KL, Badve S, et al. American Society of Clinical Oncology/College of American Pathologists guideline recommendations for immunohistochemical testing of estrogen and progesterone receptors in breast cancer. J Clin Oncol 2010;28(16):2784-95. doi: 10.1200/JC0.2009.25.6529.

21. Hanavadi S, Banerjee D, Monypenny IJ, Mansel RE. The role of tamoxifen in the management of gynaecomastia. Breast 2004;15(2):276-80. doi: 10.1016/j.breast.2005.04.007.

22. Lawrence SE, Faught KA, Vethamuthu J, Lawson ML. Beneficial effects of raloxifene and tamoxifene in the treatment of pubertal gynecomastia. J Pediatr 2004;145(1):71-6. doi: 10.1016/j.jpeds.2004.03.057.

23. Derman 0, Kanbur N, Kilic I, Kutluk T. Long-term follow-up of tamoxifen treatment in adolescents with gynecomastia. J Pediatr Endocrinol Metab 2008;21(5):449-54.

24. Lapid O, van Wingerden JJ, Perlemuter L. Tamoxifen therapy for the management of pubertal gynecomastia: a systemic review. J Pediatr Endocrinol Metab 2013;26(9-10):803-7. doi: 10.1515/jpem-2013-0052.

25. Lapid O, Klinkenbijl JH, Oomen MW, van Wingerden JJ. Gynaecomastia surgery in the Netherlands: What, why, who, where... J Plast Reconstr Aesthet Surg 2014;67(5):702-6. doi: 10.1016/j.bjps.2014.01.040.

26. Thiruchelvam P, Walker JN, Rose K, Lewis J, Al-Mufti R. Gynaecomastia. BMJ 2016;354:i4833. doi: 10.1136/bmj.i4833.

27. Rew L, Young C, Harrison T, Caridi R. A systemic review of literature on psychosocial aspects of gynecomastia in adolescents and young men. J Adolesc 2015;43:206-12. doi: 10.1016/j.adolescence.2015.06.007.

28. Esenboga S, Akgul S, Kanbur N, Tuzun Z, Derman O. The effects of gynecomastia on body image perception and gender roles in adolescents. Turk J Pediatr 2015;57(1):60-7. 